\title{
A Descriptive Model of Banking and Aggregate Demand
}

\author{
Jochen O. Mierau ${ }^{1}$ • Mark Mink ${ }^{2}$
}

Published online: 7 April 2018

(C) The Author(s) 2018

\begin{abstract}
We integrate a banking sector into an accessible macroeconomic framework, which then provides new insights on developments around the Global Financial Crisis. The analysis shows that growth of banking sector money supply may help explain the secular decline in long-term interest rates before the crisis. A new bank funding channel of monetary transmission clarifies why increases in central bank policy rates could not reverse this trend. Our analysis highlights the distinction between the zero lower bound and the liquidity trap, and shows that bank recapitalizations can be more effective than fiscal expansions in restoring aggregate demand after a banking crisis.
\end{abstract}

\begin{abstract}
We appreciate the valuable comments by an anonymous referee, the editor, Ben Heijdra, as well as Jan Marc Berk, Jan Willem van den End, Jakob de Haan, Skander van den Heuvel, Jan Jacobs, Gerard Kuper, Martien Lamers, Jasper Lukkezen, Steven Ongena, Joost Passenier, Sebastiaan Pool, Kasper Roszbach, João Sousa, Farindokht Vaghefi, Kieran Walsh, Frans de Weert, and Michalis Zaouras, and by participants of the 2016 Research Workshop of the Banking Analysis Task Force of the Eurosystem's Monetary Policy Committee, the Seminar Series of the Netherlands Bureau for Economic Policy Analysis, the 2017 International Conference on Macroeconomic Analysis and International Finance, and the 2017 IBEFA Summer Meeting. All remaining errors are our own. The views in this paper do not necessarily reflect official opinions of De Nederlandsche Bank (DNB). An earlier version of this paper was circulated as DNB Working Paper 2016-500.
\end{abstract}

$凶$ Jochen O. Mierau

j.o.mierau@rug.nl

Mark Mink

m.mink@dnb.nl

1 Faculty of Economics and Business, University of Groningen, P.O. Box 800, 9700 AV Groningen, The Netherlands

2 De Nederlandsche Bank (DNB), P.O. Box 98, 1000 AB Amsterdam, The Netherlands 
Keywords Aggregate demand · Banking · Monetary transmission · Global financial crisis

JEL Classification E32 $\cdot$ E50 $\cdot$ E63 $\cdot \mathrm{G} 01 \cdot \mathrm{G} 21 \cdot \mathrm{G} 28$

\section{Introduction}

In the wake of the 2007 Global Financial Crisis, academics and policy makers acknowledged the need to better understand the role of banks in the macro-economy. Since then, a large literature has emerged shedding light on this topic. What has not yet emerged, however, is a descriptive analytical framework that is intelligible to a broader audience of academics, informed policy makers, and students alike. By developing such a framework we aim to fill this gap. Our framework contributes to economic policy making, as the debate on, for instance, bank regulation and banking crisis management is not the domain of macroeconomic theorists alone, but requires achieving an understanding between a wide audience of policy makers, politicians, public opinion leaders, and the electorate. ${ }^{1}$ In addition, our framework contributes to the academic debate by shedding new light on key developments around the Global Financial Crisis and the ensuing recession.

A key building block of our model is the banking sector, which intermediates funds between savers and investors and is based on Van den Heuvel (2008). Our model not only incorporates banks' role as suppliers of credit, as most macroeconomic models with banks, but also accounts for their role as suppliers of money (i.e., liquidity). In particular, banks provide money to savers by issuing short-term deposits, while they provide credit to investors by making long-term loans. In doing so, banks use short-term debt liabilities to finance long-term assets, while they are constrained by a minimum equity requirement. This requirement imposes banks to fund a minimum percentage of loans with equity, thereby limiting their leverage. As bank equity is fixed in the short run (Adrian and Shin 2011), it constrains the supply of money (e.g., Diamond and Rajan 2000; Van den Heuvel 2008) as well as the supply of credit (e.g., Van den Heuvel 2002; Woodford 2010).

To integrate the banking sector into an accessible macroeconomic framework we turn to the aggregate demand set-up initiated by Keynes (1936) and Hicks (1937), which was recently micro-founded by Michaillat and Saez (2014). This choice of model is not a coincidence: its ease of use leads Krugman (2000) to consider this framework as "superior for many practical applications". At the outset of the crisis, Mankiw (2006) describes this set-up as "the basic framework that modern students

\footnotetext{
${ }^{1}$ Rochet (2015) argues that "although many economists have tried to introduce banks and financial frictions into DSGE models, these models are too complicated with so many interacting 'blocks' (to reproduce data in the short term), that by adding another layer of complexity they lose transparency and the possibility to interpret the results". While this complexity is to some extent inevitable when going beyond the descriptive level, it may also explain the observation by Grauwe (2010) that, once the crisis broke out, policy makers "did not ask the advice of [those] who knew how to solve complex DSGE models," but "went straight back to the things that were taught in macroeconomic textbooks of 40 years ago $[\ldots]$ and massively increased budget deficits and flooded the money markets with hundreds of billions of dollars of liquidity".
} 
learn to make sense of the business cycle", while Woodford (2010) uses it to convey the implications of the crisis for macroeconomic analysis. Most recently, Blanchard (2016) explains to "strongly believe that ad hoc macro models, from various versions of the IS-LM to the Mundell-Fleming model, have an important role to play in relation to DSGE models. They can be useful upstream, before DSGE modeling, as a first cut to think about the effects of a particular distortion or a particular policy. They can be useful downstream, after DSGE modeling, to present the major insight of the model in a lighter and pedagogical fashion". ${ }^{2}$ For our purpose, a particular advantage of the aggregate demand model is that it allows us to straightforwardly incorporate the distinction between money and capital market interest rates and between banks' roles as suppliers of money and credit. Coincidentally, these modifications also address some of the main caveats of the model raised by Blinder (1997) and Romer (2000), with the latter's IS-MP model being a special case of our approach. ${ }^{3}$

In short, our model can be described as follows. Money is supplied by banks rather than by the central bank, and is determined by the amount of bank equity in combination with a binding equity requirement. Demand for money is driven by a transaction motive that depends on aggregate demand and a speculative motive that depends on the spread between the long-term and the short-term interest rate. With the short-term interest rate being set by the central bank to conduct monetary policy, the money market equilibrium is described by all combinations of aggregate demand and the long-term interest that equate the supply and demand for money-the LM-curve. On the capital market (i.e., the market for bank loans), a weighted average of short-term and long-term interest rates determines the return on savings and investments. The capital market is in equilibrium for all combinations of aggregate demand and the long-term interest rate that equate the supply and demand for capital-the IS-curve. The demand-side equilibrium is then described by the simultaneous equilibrium of the money and capital market. Hence, in equilibrium, aggregate demand and the long-term interest rate are endogenously determined by, amongst others, the central bank's short-term interest rate and the supply of money generated by the banking sector.

In addition to being easy to use, our model sheds new light on key developments observed around the 2007 Global Financial Crisis and the ensuing recession. Four findings stand out in particular. First, our model suggests that part of the secular decline in the long-term interest rate prior to the crisis may have been driven by an increase in banking sector money supply. Usually, the downward trend in long-term interest rates is attributed to a global 'savings glut' stemming from an increasing supply of savings relative to investment demand (e.g., Bernanke 2005; Greenspan 2010; IMF 2014). Our framework can incorporate this development through an increase of the savings rate, but in addition highlights a role for the growing supply of bank

\footnotetext{
2 This point is developed in more detail in the recent Special Issue of the Oxford Review of Economic Policy Rebuilding Macroeconomic Theory (Vines and Wills 2018) in which, among others, Wren-Lewis (2018), Blanchard (2018), Stiglitz (2018) and Krugman (2018) discuss the future (and past) of macroeconomic models.

3 While abstracting from the role of banks, Lukkezen et al. (2015) use the IS-MP model to study fiscal and monetary policy effectiveness when monetary policy is at the zero lower bound and when firms are recovering from balance sheet problems.
} 
money made possible by rising bank equity values. Between 2000 and mid-2007, these equity values outperformed the stock market by as much as $50 \%$ points. In the model, this enables banks to substantially increase the supply of money, for instance through increasing their supply of liquid asset backed securities as witnessed during the pre-crisis years. Just as in the standard model, and irrespective of the effects of a rising savings rate, such an increase in the money supply lowers the long-term interest rate.

Second, our model suggests a new monetary transmission channel which may explain the 'interest rate conundrum' first pointed out by Greenspan (2005). This conundrum describes the apparent unresponsiveness of the long-term interest rate to changes in the short-term interest rate. As a result, central banks' pre-crisis attempts to raise long-term interest rates through monetary tightening proved largely ineffective. Our model accounts for this inability by showing that monetary policy directly affects both the money and the capital market (i.e., it also shifts the IS-curve). Consider, for instance, a monetary tightening through an increase in the short-term interest rate. It is well known that this stimulates money demand and thereby causes the long-term interest rate to rise. However, in our model also the capital market is directly affected because banks pass on their higher short-term funding costs to their borrowers, who react by lowering investment spending. This second mechanism renders the overall impact of monetary policy on the long-term interest rate ambiguous. We refer to this mechanism as the bank funding channel of monetary transmission, and note that it complements the interest rate, bank lending (Bernanke and Blinder 1988), and bank capital channel of monetary policy transmission (Van den Heuvel 2002).

Third, our model highlights that a bank recapitalization can be a particularly powerful policy instrument to restore aggregate demand in the wake of a banking crisis, even when this recapitalization is financed with a tax increase rather than through deficit spending. In fact, the model allows us to derive a bank equity multiplier that is reminiscent of the government spending multiplier. Comparing the two reveals that the former is generally larger than the latter. Comparatively small changes in bank equity can therefore have large effects on aggregate demand, in line with the large decline in economic activity observed after the Global Financial Crisis. While part of this decline has been attributed to fiscal consolidation policies adopted after the crisis, the fact that 2015 bank equity values were still $46 \%$ below their pre-crisis level may thus have played a role as well.

Finally, by taking into account that the short-term interest rate is controlled by the central bank while the banking sector supplies the quantity of money, our model highlights the underappreciated difference between the zero lower bound and the liquidity trap. While the two are often seen as part and parcel (e.g., Krugman 1998; Eggertsson 2008), we show that both have substantially different implications for policy effectiveness. The zero lower bound involves the case where a conventional monetary expansion is no longer feasible because the short-term policy interest rate cannot decline below zero. The liquidity trap, by contrast, can also occur when interest rates are higher than zero. It involves the case where an increase in banking sector money supply can no longer reduce the long-term interest rate because this rate would then have to decline below the short-term one. The zero lower bound thus constrains the short-term interest rate while the liquidity trap constrains the long-term one. While 
being in a liquidity trap limits the impact of bank money supply on aggregate demand, it increases the effectiveness of fiscal and monetary policy. The classic result that monetary policy is ineffective in a liquidity trap thus disappears once taking into account that central banks do not control the supply of money, but instead target the short-term interest rate.

The analysis of the zero lower bound and the liquidity trap also illustrates that the traditional aggregate demand framework and Romer's (2000) IS-MP model both are special cases of our approach. More specifically, the traditional framework is obtained when monetary policy is at the zero lower bound, while the IS-MP framework is obtained when the economy is in a liquidity trap. While improving upon both models, our exercise thus shows how both are related as special cases of a more general approach. In an extension of our framework, we show that the banking sector's supply of money can be endogenized without materially affecting the model's comparative statics or the insights it generates. One advantage of endogenizing the money supply is that the analysis no longer relies on the assumption of a constant price level, which in the standard model is used to deflate the nominal money stock. A shortcoming that the model inherits from the traditional framework, however, is the absence of a mechanism for the formation of expectations, but this caveat seems hard to overcome without compromising the model's tractability.

Our analysis may also benefit future research on banking and the macro-economy that aims to go beyond the descriptive level. Recent contributions to this literature include Gerali et al. (2010), Gertler and Karadi (2011), Gertler et al. (2012), Clerc et al. (2014) and Boissay et al. (2015). These studies focus on the role of banks in supplying credit to the real economy but do not incorporate their role as suppliers of money. This omission may stem from the belief discussed by Woodford (2010) that central banks can easily offset a decline in bank money supply by increasing the provision of reserves to the banking sector. But as the model by Van den Heuvel (2008) and the present analysis illustrate, a decline in bank equity reduces money supply even if banks are not required to hold reserves in the first place. Belongia and Ireland (2006) and Goodfriend and McCallum (2007) incorporate a role for bank money supply, albeit without allowing a role for bank equity. Moreira and Savov (2014) and Brunnermeier and Sannikov (2015) recently highlight the key role of financial intermediaries as suppliers of money to the real economy. Inspired by these contributions, we hope that our paper may assist both scholars and policy makers in exploring the interaction between banking and aggregate demand.

The remainder of the paper is set up as follows. In the next section we incorporate a banking sector in a descriptive model of aggregate demand and characterize its equilibrium. In Sect. 3 we illustrate the model's properties by analyzing the 
role of banks in the transmission of monetary policy, the impact of changes in bank equity on aggregate demand, and the difference between the zero lower bound and the liquidity trap. Section 4 applies the model to the 2007 Global Financial Crisis, while the final section concludes. The "Appendix" collects some additional comparative static results such as the effects of an increase in government spending.

\section{The Model}

Taking the original aggregate demand model as a starting point we use this section to extend the model with a banking sector based on Van den Heuvel (2008). Essentially, our model differs from the standard aggregate demand model in two respects. First, money is supplied by the banking sector and not by the central bank. Second, the central bank performs monetary policy through adjustments of the short-term interest rate instead of by setting the supply of money. To keep the model tractable we focus on linear functional forms.

\subsection{The Banking Sector}

We display the balance sheet of the aggregate banking sector, in stylized form, in Fig. 1. The asset side of the balance sheet is composed of long-term loans $L$ while the liability side is equally stylized and consists of short-term debt liabilities $D$-referred to as 'deposits' - and shareholder equity $E$.

For the purpose of our analysis the three items in Fig. 1 cover the main characteristics of the aggregate balance sheet of the banking sector. On the asset side, loans are risky and illiquid and yield the bank lending rate $r_{b}$, see below. On the liability side, what we refer to as deposits can consist of any form of liquid financing. This includes immediately redeemable retail deposit funding, but also, for instance, liquid asset backed debt securities that banks issued to financial market participants. Furthermore,

Fig. 1 Aggregate bank balance sheet

\begin{tabular}{c|c} 
Assets & Liabilities \\
\hline L & D \\
& E
\end{tabular}


the market value of bank equity entails the buffer with which banks can absorb losses on their asset portfolio. ${ }^{4}$ The balance sheet can be summarized in the following identity:

$$
L \equiv D+E
$$

In structuring their balance sheets, banks are constrained by a minimum equity requirement. This requirement has banks fund at least a share $k \in(0,1)$ of total assets with equity so that losses on their assets are absorbed by bank shareholders rather than by bank depositors. The bank equity requirement can be interpreted as the regulatory requirement set by the bank regulator, or it can be seen as the outcome of market discipline forces. In that case, the requirement reflects the minimum amount of equity that banks need to have in order to ensure depositors that their deposits are safe, so as to prevent them from starting a bank run. As in the absence of such a requirementregardless of whether it arises through market discipline or regulation-banks would finance all their assets with relatively cheaper deposits, the constraint will bind and total equity equals:

$$
E=k L \text {. }
$$

Hence, a higher equity requirement reduces the amount of leverage in the banking sector.

Combining (1) and (2) provides a straightforward expression linking deposits to bank equity:

$$
D=m E, \text { with } m \equiv \frac{1-k}{k}
$$

where $m$ can be interpreted as the deposit multiplier of bank equity. For a given value of $E$, the amount of deposits decreases if the equity requirement $k$ tightens. ${ }^{5}$ The intuition behind this comparative static effect is that higher equity requirements allow banks to hold fewer assets for a given amount of equity, which through the balance sheet identity implies they can also have fewer deposits. Hence, as bank equity behaves as a predetermined variable (see Adrian and Shin 2011), and in line with Diamond and Rajan (2000) and Van den Heuvel (2008), the total amount of deposits is constrained by the amount of equity in the banking sector. ${ }^{6}$

\footnotetext{
4 Bank equity in the model could also be interpreted in terms of book values rather than market values. We focus on market values as this is also what banks' (uninsured) financiers do when determining whether their claims are safe and liquid. In fact, as shown by Flannery (2015), book value measures of bank equity are least informative during a crisis, with their stability during the past decade suggesting that there never was a crisis to begin with.

5 Under the Basel III Accord banks are required to meet a regulatory equity (leverage) requirement of $k=0.03$, leading to a multiplier $m$ of roughly 30. In practice banks may hold a couple of percentage points of equity in excess of the regulatory requirement, leading to a somewhat lower $m$.

6 In the long run, bank equity is less likely to be predetermined than in the short run, as banks can increase their equity by issuing new shares and by retaining earnings while they can reduce their equity by buying back existing shares and by paying dividends. Section 3.2.1 analyses the case where bank equity is endogenous.
} 
The objective of the banking sector is to make long-term loans financed with shortterm deposits in such a way as to maximize profits. In particular, banks are price-takers and maximize profits according to:

$$
\begin{aligned}
\Pi=\max _{L, D}\left(L r_{b}-D r_{s}-E r-L r_{\sigma}\right) \\
\text { s.t. } L \equiv D+E, E=k L,
\end{aligned}
$$

where $\Pi$ indicates aggregate profits, $r_{b}$ is the bank lending rate, $r_{s}$ is the risk-free short-term interest rate, and $r$ denotes the risk-free long-term interest rate. In addition, $r_{\sigma}$ denotes a risk-premium that banks pay to their financiers. If the equity requirement is sufficiently high for deposits to remain risk free, $L r_{\sigma}$ goes to bank shareholders so that the return on equity equals $r+\frac{L}{E} r_{\sigma}$ and the return on deposits equals $r_{s}$.

Solving (4) yields the following expression for the bank lending rate:

$$
r_{b}=k r+(1-k) r_{s}+r_{\sigma}
$$

with economic profits being equal to zero $(\Pi=0)$. The rate in $(5)$ is equal to the one of Van den Heuvel (2008) except that he sets the risk-premium equal to zero. ${ }^{7}$ As can easily be verified, $r_{b}$ is equal to the bank's weighted average funding cost. The ability of banks to fund themselves with deposits thus limits the impact of the long-term interest rate on the lending rate and funding costs. Indeed, as $k$ is reduced, $r_{b}$ converges toward $r_{s}+r_{\sigma}$, which for a positive interest rate spread, i.e. $r>r_{s}$, implies that $r_{b}$ declines.

\subsection{The Money Market}

We first consider the role of the banking sector in the money market. In particular, we take into account that bank deposits constitute the supply of money to the real economy:

$$
M^{S}=D=m E
$$

where $M^{S}$ is money supply and we have used (3) to highlight the fact that the amount of money supplied is determined by the amount of equity in the banking sector. This observation contrasts with the standard LM-curve in which money supply is determined by the central bank, but is in line with recent work of McLeay et al. (2014) who explain that "the majority of money in the modern economy is created by commercial banks". Using the discussion surrounding (3) we may also infer that money supply falls as $k$ increases, which implies that higher equity requirements reduce the supply of money to the economy. ${ }^{8}$

\footnotetext{
7 The remaining difference with Van den Heuvel (2008) is that his model includes a real resource cost associated with servicing deposits and loans, which we omit for clarity of exposition.

${ }^{8}$ Earlier literature has focused on the case where central bank reserves rather than bank equity values are the binding constraint on bank money supply, so that the central bank can steer the money supply
} 
The central bank implements monetary policy by targeting the short-term interest rate. ${ }^{9}$ We incorporate this policy instrument in our model by introducing the spread between the long-term and short-term interest rate in the money demand equation:

$$
M^{D}=d Y-e\left(r-r_{s}\right),
$$

where $Y$ is aggregate demand and $d \in(0,1)$ is the parameter reflecting the transaction motive of money demand. In (7) the dependence of money demand on the interest rate spread reflects that the opportunity cost from holding liquid short-term over illiquid long-term assets is equal to the spread between the long-term and short-term interest rate. This difference is expressed in terms of the real interest rate, which is the same as the spread between nominal interest rates since the spread between inflation expectations is zero in equilibrium. ${ }^{10}$

Combining (6) and (7) provides the LM-curve:

$$
Y=\frac{e}{d}\left(r-r_{s}\right)+\frac{m}{d} E .
$$

Viewing the LM-curve in a $(Y, r)$ space, reveals that changes to either bank equity, the short-term interest rate or the equity requirement $k$ contained in $m$ can cause the curve to shift.

\subsection{The Capital Market}

The supply of capital (i.e., savings) is equal to:

$$
S=(1-c) Y+f r_{b},
$$

where $c \in(0,1)$ is the marginal propensity to consume. The parameter $f$ measures the sensitivity of savings to changes in the return on capital, which is $r_{b}$ as this is

\footnotetext{
Footnote 8 continued

to the economy by changing the supply of reserves. In practice, however, the reserve requirement has become obsolete as central banks supply any amount of reserves demanded by the banking sector at the prevailing policy interest rate (Kydland and Prescott 1990). Consequently, this policy deems the reserve based 'money multiplier' redundant, as is discussed in more detail by Benes and Kumhof (2012). By 2010, some countries had abolished reserve requirements altogether, including the United Kingdom, Canada, Denmark, and Sweden (Gray 2011).

${ }^{9}$ Briefly speaking, the central bank can control the short-term money market interest rate by announcing a policy interest rate against which it is willing to lend to and borrow from the banking sector. With this outside option available, no bank will lend to another bank against an interest rate below this target, and no bank will borrow from another bank against an interest rate above the target.

${ }^{10}$ Blinder (1997) points out that the aggregate demand framework does not distinguish between the shortterm and the long-term interest rate. Romer (2000) highlights that the central bank is assumed to conduct monetary policy by changing the money supply, whereas in practice it adjusts the short-term nominal interest rate. In addition, he points out that the model does not distinguish between the nominal interest rate determining the money market equilibrium and the real interest rate determining the capital market equilibrium. Our modifications of the money market equilibrium provide a straightforward manner to address each of these caveats.
} 
the weighted average return on all deposit and equity holdings in the economy. This setup generalizes the standard model, which lets the savings function depend on $r$ as it assumes that all savings earn the long-term interest rate. Instead, we take into account that a part of savings is held in the form of bank deposits and therefore earns the short-term interest rate.

Demand for capital (i.e., investments) is given by:

$$
I=i Y-b r_{b}
$$

where $i \in(0,1)$ is the marginal propensity to invest and $b$ measures the sensitivity of firms' investment demand to changes in the cost of capital, which is the bank lending rate derived in (5). In contrast to the original model, we take into account that firms do not borrow against the long-term rate $r$, but obtain loans from banks whose funding costs partially depend on the short-term interest rate.

We allow for government deficit spending $G$ in order to compare any consequences of central bank policy or changes in bank equity with those of fiscal policy. Therefore aggregate capital demand in the economy is given by: $I^{A}=I+G$.

Imposing $I^{A}=S$, substituting (5) and some rewriting yields the IS-curve:

$$
Y=\frac{1}{s}\left(G-(b+f)\left(k r+(1-k) r_{s}+r_{\sigma}\right)\right),
$$

where we made the standard, though often left implicit, assumption that $s \equiv 1-c-i>$ 0 to ensure that the IS-curve is downward sloping (e.g., Blanchard and Fischer 1989, p. 530). We notice immediately that the conventional monetary policy instrument $\left(r_{s}\right)$ enters the expression as well. That is, while the capital market equilibrium does not depend on the supply of money, it does depend on the short-term interest rate. Hence, by taking into account that banks fund long-term loans with short-term deposits, the interest rate on which is determined by the central bank interest rate, monetary policy directly affects both the money market and the capital market.

\subsection{Equilibrium}

The equilibrium is given by the intersection between the IS-curve in (11) and the LM-curve in (8). At that point both the money and capital market are in equilibrium. Equating the IS and LM-curve and solving for $Y$ and $r$, respectively, provides:

$$
\begin{aligned}
Y & =\frac{e}{d k(b+f)+e s}\left(G-(b+f)\left(r_{s}+r_{\sigma}\right)-\frac{s m}{d} E\right)+\frac{m}{d} E, \\
r & =\frac{d}{d k(b+f)+e s}\left(G-(b+f)\left(r_{s}+r_{\sigma}\right)-\frac{s m}{d} E\right)+r_{s} .
\end{aligned}
$$

Viewed through the lens of the expectations hypothesis of interest rates, we note that the equilibrium value for $r$ in (12b) can be interpreted as the sum of the short-term interest rate and a term-premium, with an expression for the latter being obtained after 
Fig. 2 Equilibrium in the model

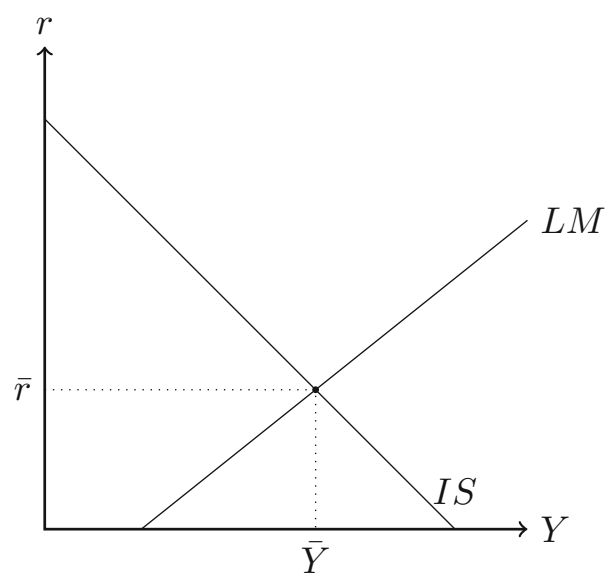

subtracting $r_{s}$ from both sides of the equation. ${ }^{11}$ Later on we return to this interpretation when discussing the liquidity trap. Figure 2 graphically displays the equilibrium of the model, showing that it consists of a downward sloping IS-curve and an upward sloping LM-curve.

\section{Policy Analysis}

Before turning to the Global Financial Crisis in Sect. 4, we use this section to highlight a number of novel features of our model in isolation. In doing so, as the model is purely descriptive and abstains from aggregate supply considerations, we avoid any claims about the optimality of specific economic policies. Instead, we show how the model establishes a new transmission channel of central bank monetary policy, illustrates the impact of changes in banking sector money supply when equity values change, and uncovers the difference between the zero lower bound and the liquidity trap. The "Appendix" collects some further comparative static effects on fiscal policy, changes in the risk premium, and changes in bank equity requirements.

\subsection{Central Bank Monetary Policy}

The impact of a change in the short-term interest rate on aggregate demand can be obtained by considering the derivative of (12a) with respect to $r_{s}$ :

$$
\frac{\partial Y}{\partial r_{s}}=-(b+f) Y_{G}=Y_{r_{s}}<0,
$$

\footnotetext{
11 The difference between $r$ and $r_{s}$ can also be interpreted as the sum of the term-premium and a liquiditypremium, where the latter reflects the liquidity services that are associated with holding bank deposits instead of bank equity. See Hanson et al. (2015) for a recent analysis of how providing such liquidity services is a key aspect of banks' business models.
} 
Fig. 3 Monetary contraction

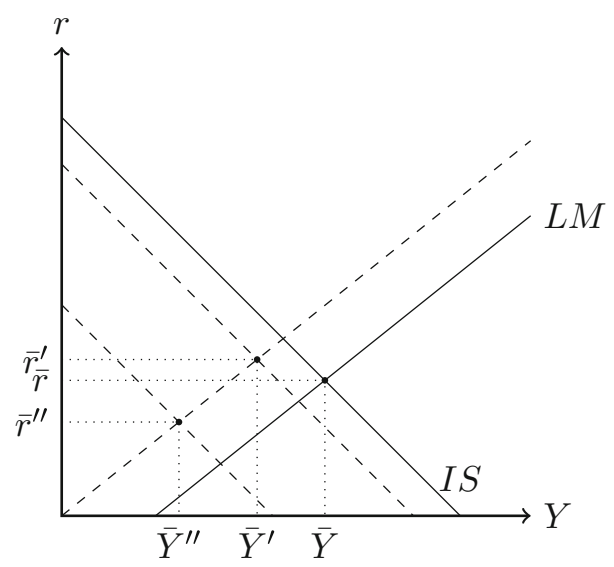

where $Y_{G}=\frac{e}{d k(b+f)+e s}>0$ is the government spending multiplier, which may be derived from (12a) as is done in the "Appendix". $Y_{r_{s}}$ is unambiguously negative, implying that a monetary tightening lowers aggregate demand. The impact of a change in the short-term interest rate on the long-term interest rate is given by:

$$
\frac{\partial r}{\partial r_{s}}=1-(b+f) \frac{d}{e} Y_{G} \gtreqless 0,
$$

which can either be positive or negative. Indeed, the impact of $r_{s}$ on $r$ depends crucially on the relative sensitivities of the LM and IS-curve to changes in $r_{s}$. If the former is more sensitive than the latter, implying $\frac{e}{d}>\frac{1}{s}(b+f)(1-k)$, both interest rates will move in concert, replicating the usual result that a monetary contraction raises the longterm interest rate. ${ }^{12}$ If both have the same sensitivity, $r$ is independent of $r_{s}$. Finally, if the IS-curve is more sensitive than the LM-curve, there is a negative relationship between $r_{s}$ and $r$. Figure 3 displays two alternative IS-curves to illustrate the possible ways in which an increase in the short-term interest rate can affect aggregate demand and the long-term interest rate. In both cases the LM-curve and IS-curve shift inward. However, depending on the magnitude of the shift of the IS-curve, the new long-term interest rate may be either higher or lower than before.

The limited impact of monetary policy on the long-term interest rate does not imply that monetary policy is ineffective in changing aggregate demand. On the contrary, the shift of the IS-curve in Fig. 3 dampens the impact of monetary policy on the long-term interest rate, but amplifies its impact on aggregate demand. The fact that monetary policy also affects the capital market equilibrium may help explain the 'interest rate conundrum' pointed out by Greenspan (2005) and analyzed by Adrian et al. (2010). The latter describe how the Federal Reserve raised its policy rate from

12 This condition holds for $k=1$ as it then simplifies to $\frac{e}{d}>0$. However, for the opposite case $k=0$, the condition becomes $\frac{e}{d}>\frac{b+f}{s}$, which need not hold in practice. 
1 to $5.25 \%$ between June 2004 and June 2006, while the 10-year US Treasury yield only increased from 4.73 to $5.11 \%$. This limited impact of monetary policy on the long-term interest rate is hard to account for in the absence of a shift in the IS-curve, but follows naturally from our model in which monetary policy affects the money market as well as the capital market.

\subsubsection{Monetary Policy Transmission}

The impact of monetary policy on the LM-curve in our model is in line with the wellknown interest rate channel of monetary transmission. An increase in the short-term interest rate increases households' demand for short-term assets (bank deposits) and reduces their demand for long-term assets (bank equity), which causes the long-term interest rate to rise and aggregate demand to fall. However, the empirical literature reviewed by Peek and Rosengren (2014) indicates that this mechanism creates an empirical puzzle, as monetary policy shocks that had relatively small effects on the long-term interest rate appear to have had substantial effects on aggregate demand. ${ }^{13}$

In order to address this puzzle Bernanke and Blinder (1988) and Kashyap and Stein (1994) suggest the so-called bank lending channel of monetary policy while Van den Heuvel (2002) suggests the bank capital (i.e., equity) channel. Under the former, the central bank tightens monetary policy by reducing the supply of reserves to the banking sector which causes banks to limit their supply of loans to the economy. Under the latter, a monetary tightening is effectuated through an increase in the short-term interest rate, which in turn reduces bank profits and, thereby, the value of their equity. By means of the equity requirement, banks then need to reduce the amount of loans provided to the economy. Hence, in both cases, rather than through the money market, the transmission of a monetary policy contraction is achieved through a reduction in loans supplied to the economy, which leads to a reduction in aggregate demand.

Supplementing these channels, our model highlights an additional mechanism through which banking interacts with the transmission of monetary policy. This mechanism differs from the aforementioned channels, in that it neither relies on a change in the supply of central bank reserves (which are absent in the model) nor on a change in the value of bank equity. In fact, in our model the impact of monetary policy on the IS-curve in (10) is largest if $k=0$. That is, when banks are not required to hold equity. As a monetary contraction increases banks' short-term funding costs (which translates into higher lending rates and lower investment demand), we refer to this transmission mechanism as the bankfunding channel of monetary policy. As the shift of the IS-curve is larger for lower values of $k$, we conclude that the ability of banks to finance long-term loans with short-term deposits amplifies the impact of monetary policy on aggregate demand while dampening — and possibly even reversing - its impact on the long-term interest rate. Hence, while the bank-funding channel comple-

\footnotetext{
13 See also Beck et al. (2014) for a recent overview of various monetary transmission channels involving banks. In addition, Borio and Zhu (2012) highlight how monetary policy can also affect risk-taking in the economy.
} 
ments the transmission channels mentioned before, the mechanism behind it is quite different. $^{14}$

\subsubsection{Inflation and the Taylor Principle}

For simplicity, the above exposition assumes that monetary policy targets the shortterm real interest rate, but in practice it targets the nominal one. Both interest rates are related through the Fisher equation $i_{s} \equiv r_{s}+\pi^{e}$, where $i_{s}$ is the nominal short-term interest rate and $\pi^{e}$ denotes expected inflation. Substituting this expression into (12a) yields:

$$
Y=\frac{e}{d k(b+f)+e s}\left(G-(b+f)\left(i_{s}+r_{\sigma}-\pi^{e}\right)-\frac{s m}{d} E\right)+\frac{m}{d} E,
$$

which implies a positive relationship between aggregate demand and expected inflation (the comparative statics for $i_{s}$ are the same as the ones for $r_{s}$ that were discussed above). Intuitively, holding the nominal short-term interest rate fixed, higher expected inflation implies a lower real short-term interest rate, and therefore higher aggregate demand. In practice, however, the central bank does not keep the nominal short-term interest rate constant if expected inflation increases. Instead, it responds to expected inflation according to, for example, $i_{s}=r_{s}^{*}+\pi^{e}+q\left(\pi^{e}-\pi^{*}\right)$, where $r_{s}^{*}$ denotes the 'natural' short-term real interest rate and $\pi^{*}$ denotes the central bank's inflation objective. For $q>0$, this monetary policy rule is in line with the Taylor principle, which implies that an increase in expected inflation leads to a higher real short-term interest rate. Substituting this monetary policy rule in (15a) yields:

$$
Y=\frac{e}{d k(b+f)+e s}\left(G-(b+f)\left(r_{s}^{*}+r_{\sigma}+q\left(\pi^{e}-\pi^{*}\right)\right)-\frac{s m}{d} E\right)+\frac{m}{d} E,
$$

which yields the familiar negative relationship between aggregate demand and expected inflation. ${ }^{15}$ Figure 4 displays the relationship between aggregate demand and expected inflation that is implied by each expression, which is typically referred to as the dynamic aggregate demand (DAD) curve. Notably, these DAD-curves were directly derived from the IS-LM equilibrium, while under the standard model they

\footnotetext{
14 To explain the limited impact of monetary policy on the long-term rate, Adrian et al. (2010) suggest that a monetary contraction reduces aggregate demand by flattening the spread between the long-term and shortterm interest rate. This decline in the spread then reduces the profitability of bank lending to the real economy, which leads them to restrict their supply of credit and thereby reduces aggregate demand. Under the bank funding channel, by contrast, a monetary contraction reduces investment by increasing the bank lending rate. The fact that the monetary contraction also flattens the interest rate spread actually dampens its negative impact on aggregate demand, which follows from writing the lending rate as $r_{b}=r_{s}+k\left(r-r_{s}\right)+r_{\sigma}$ and observing that it declines as the interest rate spread flattens.

15 Because expected inflation is exogenous in the model, the expression implies a positive relationship between aggregate demand and the inflation objective $\pi^{*}$. However, if the central bank would adopt a higher inflation objective this would probably lead to a similar increase in expected inflation, in which case aggregate demand remains unchanged.
} 
Fig. 4 Aggregate demand and expected inflation. Note the downward sloping line refers to the standard case where monetary policy is implemented according to the Taylor principle, while the upward sloping line refers to the case where the nominal short-term interest rate is instead kept constant

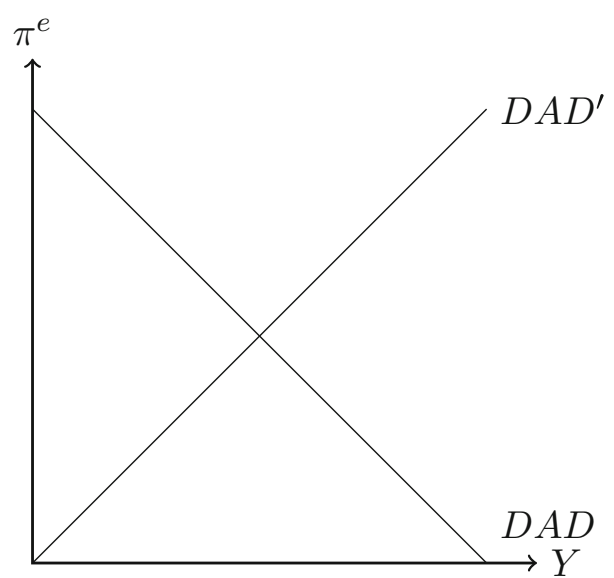

can only be obtained after dropping the LM-curve and replacing it with a monetary policy rule. By dropping the LM-curve, however, the DAD-curve that results cannot be used to analyze the effect of changes in the money supply.

\subsection{Banking Sector Money Supply}

Our model features an important role for bank equity in determining aggregate demand, as bank equity determines the supply of money in the economy. We hereby contrast the earlier view that changes in money supply are driven by monetary policy, which, as outlined above, is actually executed through changes in the short-term interest rate. The impact on aggregate demand due to changes in bank equity is determined by reference to (12a):

$$
\frac{\partial Y}{\partial E}=\left(1-s Y_{G}\right) \frac{m}{d}=Y_{E}>0
$$

which is unambiguously greater than zero. ${ }^{16}$ Moreover, if:

$$
\frac{1}{d / m+s}>Y_{G}
$$

the bank equity multiplier, $Y_{E}$ will be larger than the government spending multiplier $Y_{G}$. As this inequality holds for all plausible parameter constellations, the model implies that the bank equity multiplier is larger than the government spending multi-

16 To see this, use $Y_{G}=\frac{e}{d k(b+f)+e s}$ to observe that $s Y_{G} \in(0,1)$. Notably, changes in bank equity only affect aggregate demand as long as the equity requirement in (2) is binding. In practice, a sudden decline of bank equity during a financial crisis may therefore have a larger impact on aggregate demand than a sudden increase of bank equity during normal times. 
plier. ${ }^{17}$ This result implies that for an equivalent increase of government spending and bank equity, the latter will have a larger impact on aggregate demand than the former.

We obtain the impact of a change in bank equity on the long-term interest rate by taking the first order derivative of (12b) with respect to $E$ :

$$
\frac{\partial r}{\partial E}=-\frac{s m}{e} Y_{G}<0,
$$

which is unambiguously negative. An increase in bank equity thus lowers the long-term interest rate. Observing that (12b) implies that $\frac{\partial r}{\partial G}=\frac{d}{e} Y_{G}>0$ (see "Appendix"), and acknowledging that in practice $s m>d$ shows that, in absolute value, changes in bank equity $E$ have a larger impact on the long-term interest rate than equally large changes in deficit-financed government spending $G$. Hence, when compared to fiscal policy, changes in bank equity have a more pronounced impact both on aggregate demand and on the long-term interest rate, which highlights that bank equity is a prominent determinant of equilibrium outcomes. The equilibrium impact of a decline in equity is displayed in Fig. 5. This effect is qualitatively similar to that of a decline in the money supply in the original model, in which the money supply is determined by the central bank.

\subsubsection{Extension: Endogenous Equity}

Similar to the assumption of exogenous central bank money supply in the standard model, in our model bank equity and, thereby, banking sector money supply is exogenous. While this facilitates drawing parallels with the standard model, the current model can be modified to let the money supply be determined endogenously. To do so we take into account that for the stock of outstanding loans $L$ to be constant in equilibrium, the flow of newly made loans has to be equal to the flow of maturing loans that are being repaid. If this were not the case, the bank's loan portfolio would either grow in size indefinitely or would over time shrink towards zero. If we set the flow of maturing loans equal to a fraction $a \in(0,1)$ of the stock of loans $L$, and if we take into account that the flow of newly made loans is equal to total investment $I$, this intuition can be formalized as:

$$
I=a L
$$

\footnotetext{
17 To see this, we note that the condition is less likely to hold for larger values of $d, k$, and $s$, but is still met for implausibly high values of these parameters. For instance, suppose $k$ is equal to 0.1 , which is substantially higher than the Basel III regulatory leverage requirement of 0.03 . Furthermore, assume $d$ is equal to 1, which is considerably larger than the ratio of broad money (M3) to GDP in the U.S., which lies between 0.5 and 0.65 (FRED 2015). Finally, the worldwide average savings rate equals 0.21 (World Bank 2015), which if equated to the marginal savings rate $1-c$ implies that $s \equiv 1-c-i$ is considerably below this number. Setting $s$ considerably higher at 0.3 shows that the equality holds for any $Y_{G} \leq 2.4$, which is well above the 1.7 that Blanchard and Leigh (2013) suggest as the upper bound for the government spending multiplier worldwide. For any less extreme values for $k, d$ and $s$, the cut-off value for $Y_{G}$ is even higher.
} 
Fig. 5 Bank equity decline

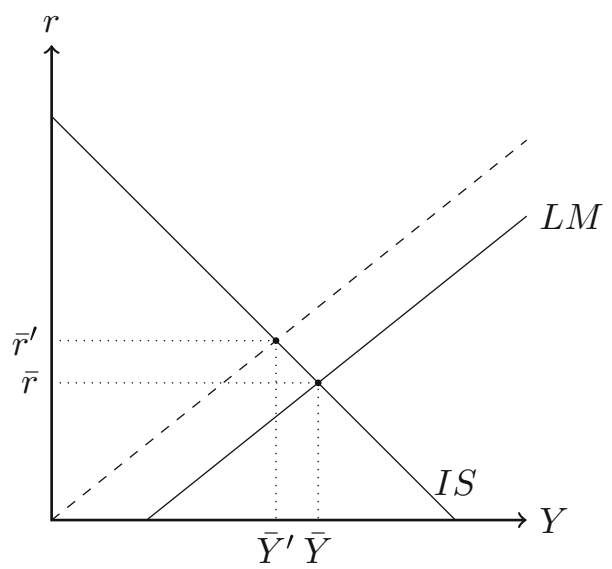

Using the investment function in (10) and the bank equity requirement in (2), this expression can be rewritten as an expression for $E$, which can then be substituted in (8) to obtain a version of the LM-curve with endogenous equity:

$$
Y=\frac{a e-(1-k) k b}{a d-(1-k) i}\left(r-r_{s}\right)-\frac{(1-k) b}{a d-(1-k) i}\left(r_{s}+r_{\sigma}\right) \text {. }
$$

The "Appendix" proves that $a e>(1-k) k b$ if we assume that $i<\frac{a d}{1-k}$ [in addition to the assumption $i<1-c$ made under (5)], which ensures that aggregate demand is positive and the LM-curve slopes upward. The money market equilibrium then implies that a monetary contraction has a negative effect on aggregate demand, while as a new result it shows that an increase in the risk premium has such a negative effect as well. Note that by endogenizing the banking sector's supply of money, the model's equilibrium depends on real variables only (see also footnote 10). This allows us to drop the (so far implicit) assumption from the standard model that the nominal money supply can be deflated using a constant price level.

The IS-curve in (11) remains the same as before, as it does not depend on bank equity. Hence, endogenizing bank equity only affects the comparative statics of the model to the extent that it changes the comparative statics of the LM-curve. The "Appendix" shows that in equilibrium, these comparative statics are qualitatively unchanged as aggregate demand and the long-term interest rate still depend positively on government spending and negatively on the risk-premium. Also, aggregate demand depends negatively on the short-term interest rate while the impact thereof on the long-term rate remains ambiguous. As the model with endogenous equity is somewhat less tractable than the one where equity is exogenous, we focus on the case of exogenous bank equity for the remainder of the paper. 


\subsection{Zero Lower Bound Versus Liquidity Trap}

By letting the central bank control the short-term interest rate while the banking sector supplies the quantity of money, the model allows to highlight the distinction between the zero lower bound and the liquidity trap. The zero lower bound affects contemporary monetary policy, as it concerns the situation that once the nominal short-term interest rate has hit zero, it is no longer feasible to decrease it any further. After all, once the nominal short-term rate arrives at zero, a further decline would cause savers to withdraw their bank deposits and hoard cash instead. ${ }^{18}$ As the nominal short-term rate equals $i_{s} \equiv r_{s}+\pi^{e}$, the zero lower bound can be defined as the constraint that $r_{s} \geq-\pi^{e}$. Although a conventional monetary expansion is infeasible at the zero lower bound, the other properties of the model remain unaffected. That is, setting $r_{s}=-\pi^{e}$ in (12a) and (12b) does not change how aggregate demand and the long-term interest rate are determined. As we will see, the zero lower bound in this way differs markedly from a liquidity trap.

Indeed, our analysis sheds new light on the liquidity trap and its impact on the efficacy of monetary and fiscal policy. In a liquidity trap an expansion of the money supply, which in our model results from an increase in bank equity $E$, is fully absorbed by an increase in money demand without lowering the interest rate on savings and investment. Aggregate demand therefore remains unchanged. Typically, e.g., Eggertsson (2008), this situation is associated with monetary policy being at the zero lower bound, as is illustrated by Krugman (1998) observation that "a liquidity trap may be defined as a situation in which conventional monetary policies have become impotent, because nominal interest rates are at or near zero". However, our model shows that both concepts differ markedly from each other. In particular, the economy is in a liquidity trap when $r=r_{s}$, as a further decline of $r$ then is infeasible because savers would start selling bank equity and hoard bank deposits. As the traditional IS-LM model implicitly assumes that $r_{s}=0$, because the only short-term asset available is cash with its interest rate of zero, the liquidity trap coincides with the zero lower bound. However, by allowing for interest bearing bank deposits, our model shows that the liquidity trap can also occur for interest rates larger than zero. In particular, the liquidity trap can be interpreted as a zero lower bound on the term-premium, stating that $r-r_{s} \geq 0 .{ }^{19}$

The above implies that at $r=r_{s}$ the LM-curve becomes horizontal, which just as in the traditional model can be achieved by letting $e=\infty$ in (8). A change in the money supply through a change in $E$ then no longer affects aggregate demand or the long-term interest rate. Furthermore, viewing the government spending multiplier

\footnotetext{
18 In practice, due to the costs involved in safely storing large volumes of cash, the return on holding cash is somewhat lower than zero. As a result, the lower bound on nominal short-term interest rates is somewhat lower than zero as well, a consideration that we abstain from in the model for reasons of simplicity. For further reading on the role of cash and other aspects of the zero lower bound, see Ball et al. (2016).

19 In practice, just as the lower bound on nominal interest rates is somewhat below zero, the lower bound on the term-premium could be somewhat below zero as well. Still, the 10-year term-premium on U.S. Treasuries that is estimated by the New York Fed, which uses the methodology by Adrian et al. (2013), has been negative for less than $4 \%$ of the time since the beginning of the 1960s. See https://www.newyorkfed. org/research/data_indicators/term_premia.html.
} 
Fig. 6 Aggregate demand and expected inflation at the zero lower bound and in the liquidity trap. Note the continuous downward sloping line refers to the standard case where monetary policy is implemented according to the Taylor principle, while the continuous upward sloping line refers to the case where the nominal short-term interest rate is at the zero lower bound. The dotted lines refer to the same cases but in addition the economy is in a liquidity trap

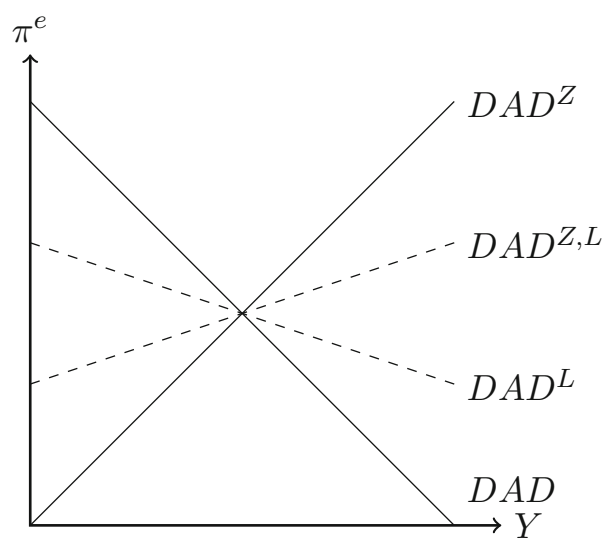

$Y_{G}=\frac{e}{d k(b+f)+e s}$ confirms the conventional wisdom that a fiscal expansion becomes particularly potent in a liquidity trap-having an impact on aggregate demand equal to $1 / s$. At the same time, with the LM-curve being flat there is no impact of fiscal policy on the long-term interest rate. More surprisingly, also the impact of monetary policy on aggregate demand is enhanced, in tandem with the impact of fiscal policy as (13) is a fixed multiple of the government spending multiplier. In addition, as $r=r_{s}$ implies that $r_{b}=r_{s}+r_{\sigma}$, a chang of the monetary policy rate in a liquidity trap translates into a one-for-one adjustment of all other interest rates in the model.

The differences between the zero lower bound and of the liquidity trap carry over to the relationship between aggregate demand and expected inflation. For example, once the zero lower bound causes the nominal short-term interest rate to be stuck at the zero, the central bank can no longer implement the Taylor principle discussed in Sect. 3.1.2. Figure 6 shows that this causes the DAD-curve to slope downward instead of upward [as for a constant nominal short-term interest rate the curve is determined by (15a)]. This dynamic aggregate demand curve is similar to the 'topsy-turvy' one analyzed in Eggertsson and Krugman (2012). By contrast, as Fig. 6 also illustrates, the liquidity trap causes the slope of the DAD-curve to flatten rather than to change sign [this follows from substituting $e=\infty$ in (15a) and in (15b)]. This flatter slope reflects that in a liquidity trap the real short-term interest rate is equal to the real long-term interest rate. A change in expected inflation therefore affects the real long-term interest rate in the same way as the real short-term interest rate, which strengthens the impact of the change in expected inflation on aggregate demand. As the figure illustrates, if the monetary policy interest rate arrives at the zero lower bound or if the economy moves into a liquidity trap, the relationship between aggregate demand and expected inflation changes considerably.

Summarizing, compared to the zero lower bound, which hinders monetary policy by imposing a constraint $r_{s} \geq-\pi^{e}$ on the short-term interest rate, the liquidity trap imposes a constraint $r \geq r_{s}$ on the long-term interest rate (i.e., a zero lower bound on the term premium) and causes the efficacy of both fiscal and (conventional) monetary policy to be enhanced. Figure 7 illustrates for the U.S. that monetary policy may be at the zero lower bound while the term-premium is larger than zero, and vice versa. 


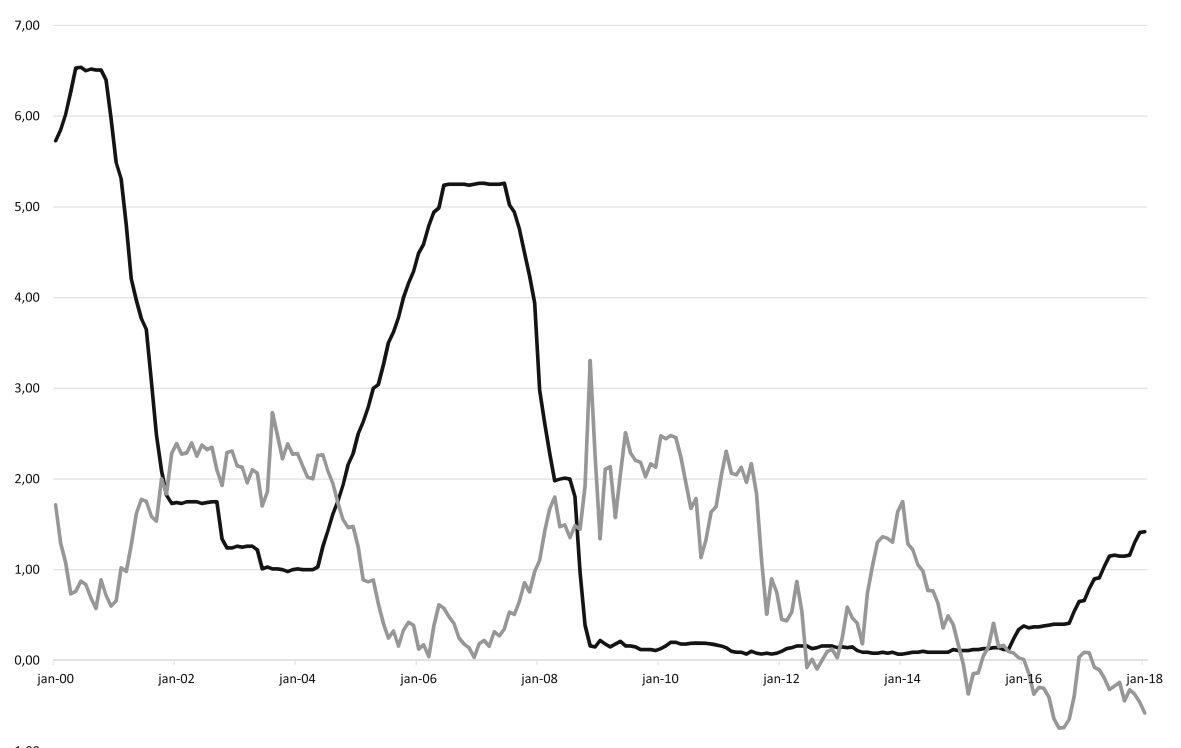

$-1,00$

Fig. 7 The zero lower bound and the liquidity trap. Note the black line displays the U.S. Federal Funds rate as obtained from the Federal Reserve Bank of St. Louis. The gray line displays the 10-year term-premium in U.S. Treasuries as obtained from the New York Federal Reserve

Hence, the zero lower bound and the liquidity trap are distinct concepts with both their own consequences. Notably, the common view that a liquidity trap renders monetary policy powerless hinges crucially on the assumption that this policy is implemented through changing the money supply, and vanishes when taking into account that central bank monetary policy involves changing the short-term interest rate.

\subsubsection{IS-LM and IS-MP as Special Cases}

A direct implication of the foregoing discussion is that our models nests the IS-LM model as well the IS-MP model as special cases. ${ }^{20}$ Indeed, the IS-LM model can be seen as a special case of our model when monetary policy is at the zero lower bound, while Romer's (2000) IS-MP model can be seen as a special case when the economy is in a liquidity trap. To obtain the traditional IS-LM model, let the risk premium $r_{\sigma}$ and (exogenous) inflation expectations $\pi^{e}$ both be equal to zero. The zero lower bound on the nominal short-term interest rate then implies $r_{s}=0$. In this case, aggregate demand in (12a) and the long-term interest rate in (12b) only depend on government deficit spending $G$ and on the supply of money $m E=M^{s}$, in a way that is observationally equivalent to the standard IS-LM framework. The IS-MP model, in addition, is obtained when the economy in our model is in a liquidity trap, i.e., when $e=\infty$. The equilibrium is then described by the IS-curve in (11) while the long-term interest rate in (12b) reads $r=r_{s}$. Assuming a monetary policy rule for

20 As an alternative to the IS-LM model, Romer (2000) develops the IS-MP model by replacing the LM-curve with a monetary policy rule such as the one by Taylor (1993). 
$r_{s}$ then yields the IS-MP model. Hence, our model generalizes both the IS-LM and the IS-MP model, as it applies also when the economy is not at the zero lower bound or in a liquidity trap and irrespective of whether the central bank follows a specific monetary policy rule.

\section{The Global Financial Crisis}

Using the insights collected above we now apply our model to the 2007 Global Financial Crisis (GFC) and the ensuing recession. We structure the analysis by distinguishing between (i) the run-up to the crisis, (ii) the outbreak of the crisis, (iii) the policy response to the crisis, and (iv) the aftermath of the crisis. For future reference, Fig. 8 depicts the main developments in bank equity, GDP growth, and the long-term real interest rate during these periods, with the shaded area indicating the 2 years following the crisis outbreak in mid-2007. We adopt this stylized distinction between crisis phases for narrative purposes and acknowledge that the actual chain of events is less clear-cut.

\subsection{Run-Up to the Crisis}

The years preceding the 2007 GFC were characterized by a marked increase in bank risk-taking (e.g., Brunnermeier 2009). Indeed, banks managed to increase their risk profiles by engaging in off-balance sheet activities that remained largely unregulated. A notable example is the originate-to-distribute model in which banks transferred mortgage, car and student loans to the balance sheets of special purposes vehicles. These entities, which were not subject to banking regulation, held almost no equity buffers and financed themselves by issuing short-term debt. These debt instruments provided their buyers with an important source of money as they could be traded easily in financial markets. By boosting profitability, the originate-to-distribute model contributed to an exceptionally large increase in the total value of bank equity. The MSCI World Banking Index rose by $65 \%$ between 2000 and its in peak in May 2007, while the MSCI World Index as a whole only increased by $15 \%$ in the same period-a $50 \%$ point difference.

Within our framework, higher bank risk taking can be modeled as a reduction in bank equity requirements $k$ (which is effectively what happens if an increasing share of banks' loans is held on the balance sheet of unregulated entities). As we show in the "Appendix" lower equity requirements boost aggregate demand, amongst others because they allow banks to supply more money for an equal amount of equity. Furthermore, the increase in bank equity values can be interpreted as an increase in $E$ within our model. As is borne out by Sect. 3.2, this provides a strong (i.e., larger than an equivalent change in government expenditures) boost to aggregate demand and depresses the long-term interest rate.

The above discussion suggests an additional explanation for the secular decline in the long-term interest rate in the run up to the GFC. In their statements before the U.S. Financial Crisis Inquiry Commission, Bernanke (2010) and Greenspan (2010) attribute this decline to an increase in savings relative to investments-especially in emerging markets. In addition, the IMF (2014) considers increased demand for safe 

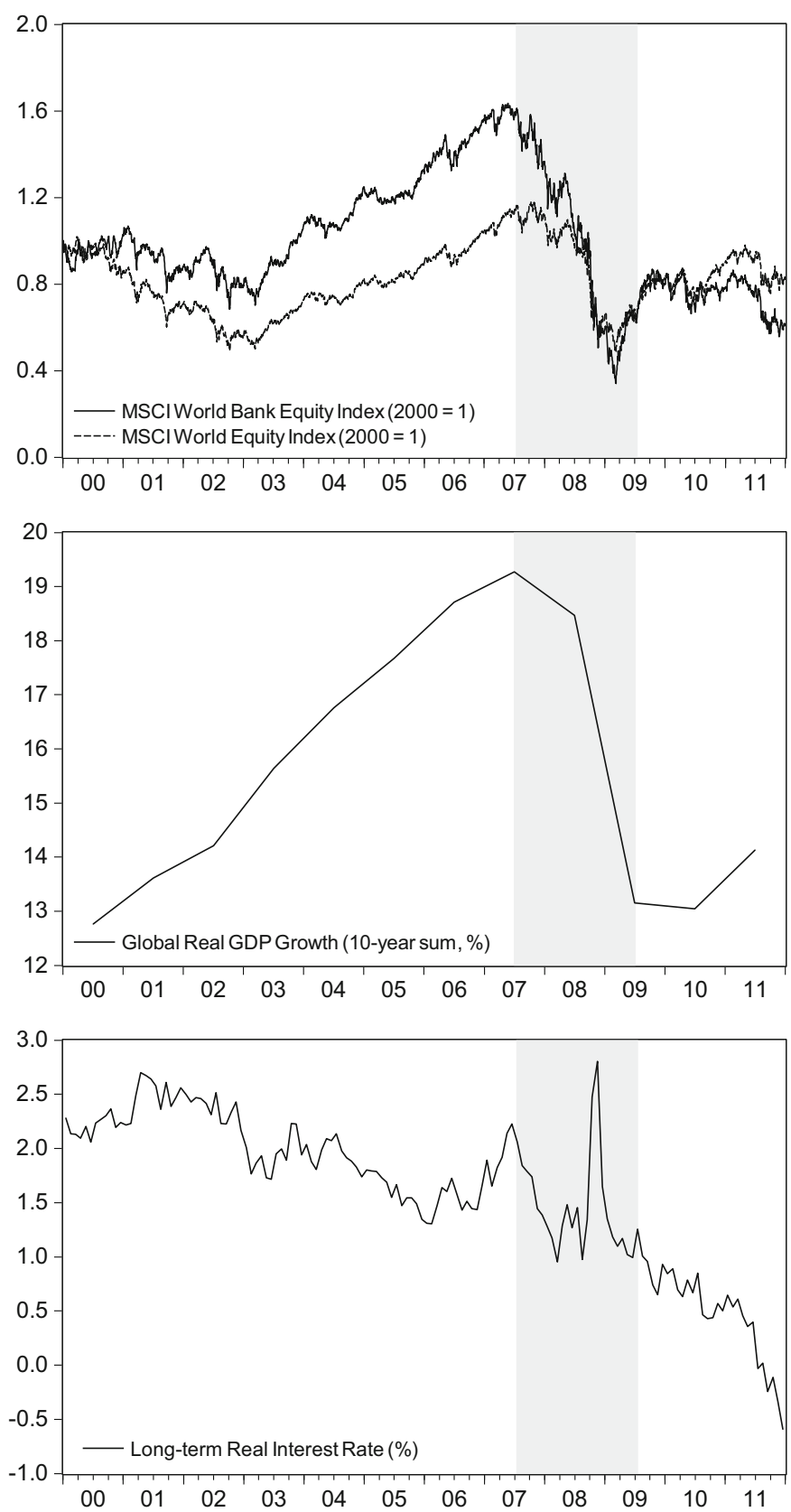

Fig. 8 Macroeconomic developments. Note the top panel displays the MSCI World Banking Equity Index and includes the MSCI World Equity Index for comparison. The middle panel displays growth per decade of global real GDP per capita, obtained from the World Bank's Global Development Indicators. The lower panel displays the long-term real interest rate, measured as the 10-year yield on inflation-indexed triple-A U.K. treasury bills (which is available for a longer time period than similar statistics for the U.S.). The shaded area comprises the 2-year period starting mid-2007 
assets to have been an important factor, and also explores the potential contribution of fiscal and monetary policy. Supplementing these views, our model suggests that part of the decline in long-term rates may have been driven by an increase in bank money supply made possible by rising bank equity values. These high equity values for instance enabled banks to issue increasing amounts of liquid asset backed securities, which may have depressed the long-term interest rate similar to the effect of a money supply expansion in the standard model. ${ }^{21}$

\subsection{Outbreak of the Crisis}

The 2007 GFC was triggered by the realization that U.S. house prises had become unsustainably high and that, therefore, U.S. mortgage backed securities were worth substantially less than initially thought. This became increasingly clear in June 2007 when investment bank Bear Stearns needed to bail out two of its hedge funds that were heavily exposed to the U.S. housing market. Financial turmoil continued as bank equity values fell, the market for asset backed securities became illiquid, and Lehman Brothers, another investment bank, collapsed in September 2008. It was not before the first half of 2009 that banks' equity values started to show some upward movement again.

Within our model the outbreak of the crisis can be seen as a sharp drop in bank equity $E$ combined with an increase in $k$ as investors are only willing to finance banks with relatively high equity buffers (a 'wake-up call'). In addition, the illiquidity of the market for asset backed securities forced banks to take these securities out of their special purpose vehicles and put them back on their own balance sheets, where they became subject to (higher) regulatory equity requirements. ${ }^{22}$ As before, the impact of a decline in $E$ can be analyzed with reference to Fig. 5, which highlights the sharp decline in aggregate demand after a decline in bank equity. This decline in aggregate demand is further aggravated by the increase of $k$. In addition, the drop in $E$ contributes to an increase in the long-term interest rate. Hence, by means of the bank equity multiplier $Y_{E}$ derived above, we can go some way in rationalizing why a decline in bank equity could have had a large impact on aggregate demand displayed in the middle panel of Fig. 8. In addition, the sudden decline in bank equity after the Lehman collapse was associated with a drastic reduction of bank money supply, which would cause a strong increase of the long-term interest rate as in the lower panel of the figure.

\footnotetext{
21 The upward trend in private sector money supply as a percentage of GDP dates back to the beginning of the 1980s, which coincides with the start of the downward trend in long-term interest rates: https://fred. stlouisfed.org/graph/?g=cM5p. The discussion of the interest rate conundrum in Sect. 3.1 highlights why monetary policy was ineffective in offsetting the decline in long-term interest rates, even though it probably had a dampening effect on aggregate demand.

22 See also Eggertsson and Krugman (2012) for an analysis of a sudden exogenous decline in the acceptable level of leverage_-a so-called Minsky moment.
} 


\subsection{Policy Response to the Crisis}

In response to the turmoil in financial markets, the Federal Reserve started to lower the Federal Funds Target Rate in September 2007. After initially reducing the Target Rate by 50 basis points, the Federal Reserve steadily reduced the rate further, eventually hitting the zero lower bound in December 2008. In tandem with the actions of the Federal Reserve, also the European Central Bank and the Bank of England both reduced their Target Rates, eventually hitting the zero lower bound as well. In spite of these large and concerted monetary expansions, the international banking sector remained notoriously unstable. Hence, in order to restore stability, policy makers required banks to recapitalize either by forcing them to withhold dividends or by issuing new shares, and in several cases bailed them out altogether (e.g., Northern Rock, ABN-Amro, and Citigroup).

The unprecedented reductions in monetary policy rates can be analysed in our model as a decline in the short-term interest rate $r_{s}$. Section 3.1 reveals that this causes and outward shift of both the LM and IS-curve leading to upward pressure on aggregate demand and to an ambiguous impact on the long-term interest rate. Once the policy rate hit the zero lower bound, the alternative option for policy makers was to provide large scale direct support to the banking sector. Such support occurred through asset purchases and guarantees but also very explicitly through bank bailouts. ${ }^{23}$ Within our model this can be considered as a direct transfer from the government to the banking sector to increase their equity $E$. In principle, in order to restore aggregate demand through a bailout, the size of the bailout should equal the amount of equity lost during the crisis, hence neutralizing the effect. However, as the crisis triggered bank financiers to demand higher equity buffers than before, the actual bail out necessary is larger than the equity loss incurred during the crisis. Still, it is much smaller than the increase in government expenditure that would be required to restore aggregate demand using a conventional fiscal expansion (see the discussion in Sect. 3.2). Bank bailouts may thus be a particularly powerful tool for restoring aggregate demand in the wake of a financial crisis. ${ }^{24}$

The above discussion sheds new light on why the drastic reduction of monetary policy rates toward the zero lower bound was unlikely to be large enough to prevent a marked shortfall in economic activity. While fiscal consolidations are sometimes presented as culprits for the decline in aggregate demand, depressed bank equity values are likely to have contributed to such a decline as well. In fact, even by the start of 2015, despite several bank recapitalization rounds, bank equity values were still $46 \%$ below their pre-crisis peak, while since then the MSCI World stock market index experienced a growth of $6 \%$. Figure 9 illustrates that this decline in equity values coincided with a fall in the issuance of asset backed securities, which were typically

\footnotetext{
23 As reserve requirements are absent, our model does not have a role for the increase in reserves supplied by central banks to stabilize the financial sector. This is in line with Kydland and Prescott (1990) observation that central banks at all times provide any desired amount of reserves to the financial sector. In that sense, Footnote 23 continued

the promise by central banks after the Lehman collapse to provide unlimited reserves to the banking sector simply confirms normal policy.

24 Naturally, the moral hazard implications of both policies are quite different.
} 
2500

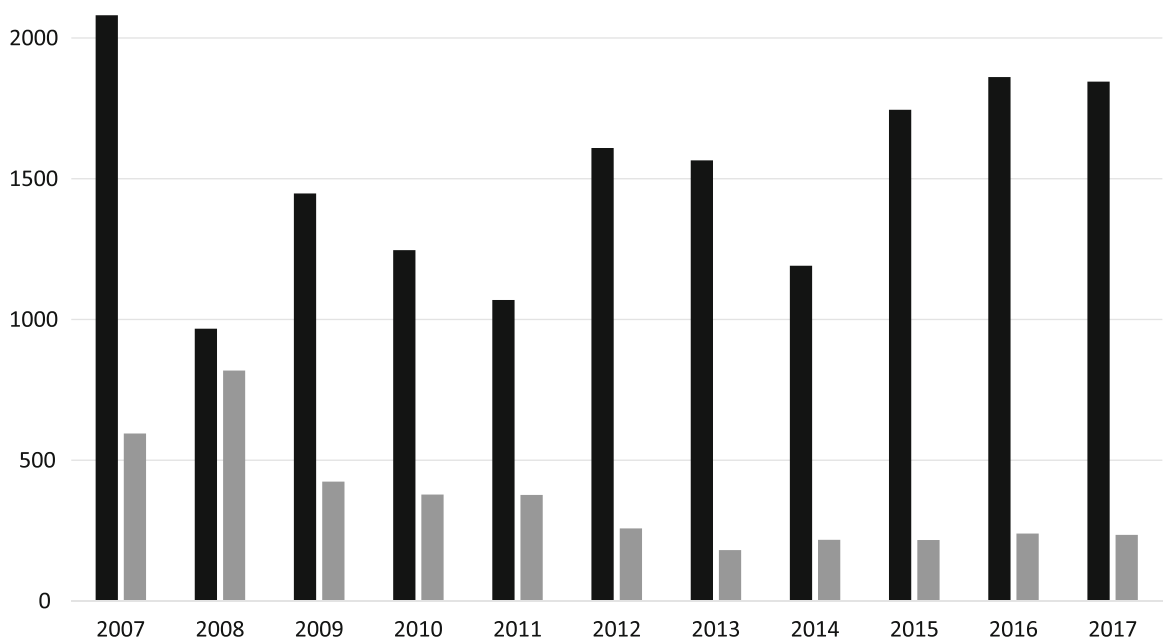

Fig. 9 Issuance of asset backed securities. Note the black bars display the issuance of asset backed securities in the United States and the gray bars display issuance in the European Union. Issuance volumes are expressed in billions of euros and are obtained from the 2017Q4 Securitisation Data Snapshot published by the Association for Financial Markets in Europe

regarded as money-like debt instruments due to their perceived safety and liquidity. Our model implies that the relatively quick recovery of issuance volumes in the U.S., as compared to issuance in the European Union, was at least partially enabled by the swifter recapitalization of U.S. banks after the crisis.

\subsection{Aftermath of the Crisis}

The slow recovery after the GFC not only reflects a decline in bank money supply but has also been attributed to depressed credit growth. While to some extent lower credit supply was a correction of pre-crisis excesses, policy makers worried that a credit crunch could impede the economic recovery. Hence, in November 2008, the Federal Reserve announced that it would start buying U.S. mortgage backed securities in financial markets in order to boost credit availability - the so-called credit easing program. Since then, the Federal Reserve accumulated over 1.5 trillion dollars worth of mortgage backed securities, which has contributed substantially to the decline of U.S. mortgage rates (Hancock and Passmore 2011). In addition, in March 2009 the Federal Reserve expanded the program by buying what would end up to be 2.5 trillion worth of U.S. Treasury securities so as to combat sliding inflation expectations- the so called quantitative easing program. Likewise, the European Central Bank and the Bank of England adopted similar policies.

Our model can be used to analyze a credit crunch by focusing on the risk premium $r_{\sigma}$ and on inflation expectations $\pi^{e}$, the latter of which were introduced in 
Sect. 3.1. The risk premium may have risen once the crisis alerted shareholders that bank loan portfolios are riskier then they thought, or once declining asset values trigger an increase in the market price of risk. Such an increase in the risk premium causes the IS-curve to shift inward, which lowers both aggregate demand and the long-term interest rate. In fact, the impact on aggregate demand of an increase in risk premiums is as large as the impact of a comparable increase in the short-term interest rate (see the "Appendix"). In addition, with monetary policy stuck at the zero lower bound, the relationship between aggregate demand and expected inflation became positive, so that the decline in aggregate demand was associated with a decline in expected inflation.

The above discussion helps to understand the slow recovery in the aftermath of the crisis. The observed increase in risk premiums $r_{\sigma}$ is likely to have depressed aggregate demand as well as the long-term interest rate. The observed decline in long-term rates should thus not be automatically interpreted as evidence that bank lending rates came down as well, but could signal that lending rates increased due to higher risk premiums (see also Daly 2016). At the same time, the decline in aggregate demand may have caused expected inflation to fall, which with monetary policy stuck at the zero lower bound implies an increase in the real short-term interest rate. ${ }^{25}$ To the extent that central banks' large scale asset purchases offset the increase in risk premiums and the decline in inflation expectations, these purchases contributed to raising aggregate demand. ${ }^{26}$

\section{Conclusion}

A caveat of the recent surge of interest in understanding the role of banks in the macro-economy is the complexity of the modeling frameworks available. Indeed, various observers have pointed out that state of the art macroeconomic models can be too complicated for even the sophisticated reader to grasp the essence of economic policy making. The present paper therefore complements the literature by integrating a banking sector in a descriptive macroeconomic model that is accessible to the broader academic community as well as to informed policy makers. Our starting point was the aggregate demand set-up, which is known for its "principal virtue [...] that many students and policy makers with little or no previous experience can, after some effort, master its mechanics, understand its intuition, and apply it to novel situations (Romer 2000). What results is a descriptive analytical framework that provides new insights on developments observed around the Global Financial Crisis. As such, we hope that the

\footnotetext{
25 The decline in inflation expectations has the same ambiguous effect on the long-term rate as an increase in the short-term rate $r_{s}$.

26 An important mechanism through which large scale asset purchases stimulate demand is by buying assets with longer maturities (i.e., government bonds) in exchange for assets with shorter maturities (i.e., central bank deposits). Such purchases lower the long-term interest rate and thereby stimulate aggregate demand. The present framework cannot analyze this policy, however, as this would require a more explicit modeling of the balance sheet of the central bank.
} 
model can assist a broader audience in thinking about the interaction between banking and aggregate demand.

Open Access This article is distributed under the terms of the Creative Commons Attribution 4.0 International License (http://creativecommons.org/licenses/by/4.0/), which permits unrestricted use, distribution, and reproduction in any medium, provided you give appropriate credit to the original author(s) and the source, provide a link to the Creative Commons license, and indicate if changes were made.

\section{Appendix: Additional Comparative Static Effects}

\section{A. Fiscal Policy}

The impact on aggregate demand of a change in debt-financed government spending (i.e., the government spending multiplier), can be assessed by taking the first order derivative of (12a) with respect to $G$ :

$$
\frac{\partial Y}{\partial G}=\frac{e}{d k(b+f)+e s}=Y_{G}>0,
$$

which reveals that the efficacy of government spending in changing aggregate demand is determined by the typical parameters - such as the savings rate $s$-as well as the bank equity requirement $k$. Since the government spending multiplier is positive, an increase in deficit-financed government spending drives up aggregate demand. Similarly, to derive the impact of government spending on the long-term interest rate we can take the first order derivative of (12b) with respect to $G$ :

$$
\frac{\partial r}{\partial G}=\frac{d}{e} Y_{G}>0
$$

which shows that an increase in government spending increases the long-term interest rate.

\section{B. Risk Premium}

The impact of a change in the risk premium on aggregate demand equals:

$$
\frac{\partial Y}{\partial r_{\sigma}}=-(b+f) Y_{G}<0
$$

which is unambiguously negative. Furthermore, the impact on the long-term interest rate equals:

$$
\frac{\partial r}{\partial r_{\sigma}}=-(b+f) \frac{d}{e} Y_{G}<0
$$


which is negative as well. An increase in the risk premium thus depresses both aggregate demand and the long-term interest rate.

\section{Bank Equity Requirements}

The impact on aggregate demand of changes in the bank equity requirement $k$ can be calculated as:

$$
\begin{aligned}
& \frac{\partial Y}{\partial k}=Y_{k}<0, \\
& \frac{\partial r}{\partial k}=r_{k} \gtreqless 0 .
\end{aligned}
$$

Inspection of (A.5) reveals that stricter equity requirements lead to lower aggregate demand. The impact of a change in equity requirements on the long term interest rate is analytically ambiguous and depends on the specific parameter constellations.

\section{Proof that $a e-(1-k) k b>0$ if $i<\frac{a d}{1-k}$}

Using $D=(1-k) L$ from (7) we know $e=\frac{d Y-(1-k) L}{r-r_{s}}$ and from (10) we know $b=\frac{i Y-I}{r_{b}}$. Using this we write:

$$
\begin{aligned}
a e-(1-k) k b & =\frac{a d Y}{r-r_{s}}-\frac{a(1-k) L}{r-r_{s}}-\frac{(1-k) k i Y}{r_{b}}+\frac{(1-k) k I}{r_{b}}, \\
& =\frac{a d Y r_{b}-(1-k) k i Y\left(r-r_{s}\right)-a(1-k) L r_{b}+(1-k) k I\left(r-r_{s}\right)}{r_{b}\left(r-r_{s}\right)}, \\
& =\frac{\left(a d r_{b}-(1-k) k i\left(r-r_{s}\right)\right) Y-\left(r_{b}-k\left(r-r_{s}\right)\right)(1-k) I}{r_{b}\left(r-r_{s}\right)}, \\
& =\frac{\left(a d r_{b}-(1-k) i\left(r_{b}-r_{s}-r_{\sigma}\right)\right) Y-\left(r_{b}-r_{b}+r_{s}+r_{\sigma}\right)(1-k) I}{r_{b}\left(r-r_{s}\right)}, \\
& =\frac{(a d-(1-k) i) Y r_{b}+\left[(1-k) i\left(r_{s}+r_{\sigma}\right) Y-\left(r_{s}+r_{\sigma}\right)(1-k) I\right]}{r_{b}\left(r-r_{s}\right)}, \\
& =\frac{(a d-(1-k) i) Y r_{b}+(1-k)\left(r_{s}+r_{\sigma}\right) b r_{b}}{r_{b}\left(r-r_{s}\right)}, \\
& =\frac{(a d-(1-k) i) Y}{r-r_{s}}+\frac{\left(r_{s}+r_{\sigma}\right)(1-k) b}{r-r_{s}} .
\end{aligned}
$$

where we used $I=a L$ in the third row and $r_{b}=r_{s}+k\left(r-r_{s}\right)+r_{\sigma}$ in the fourth. Focusing on the last row, the first term is positive by our assumption $i<\frac{a d}{1-k}$, while the second term is positive as well. This proves that $a e-(1-k) k b>0$ if $i<\frac{a d}{1-k}$. 


\section{E. Equilibrium with Endogenous Equity}

The equilibrium with endogenous equity is given by the intersection between the IScurve in (11) and the LM-curve in (19). Solving for $Y$ and $r$, respectively, provides:

$$
\begin{aligned}
Y & =\frac{\tilde{e}}{\tilde{d} k(b+f)+\tilde{e} s}\left(G-(b+f)\left(1+\frac{(1-k) k b}{\tilde{e}}\right)\left(r_{s}+r_{\sigma}\right)\right), \\
r & =\frac{\tilde{d}}{\tilde{d} k(b+f)+\tilde{e} s}\left(G-(b+f)\left(1+\frac{(1-k) k b}{\tilde{e}}\right)\left(r_{s}+r_{\sigma}\right)\right)+r_{s},
\end{aligned}
$$

where $\tilde{e}=a e-(1-k) k b>0$ and $\tilde{d}=a d-(1-k) i>0$. As before, aggregate demand and the long-term interest rate depend positively on government spending and negatively on the risk-premium. The short-term interest rate, furthermore, negatively affects aggregate demand and has an ambiguous impact on the long-term interest rate.

\section{References}

Adrian, T., Crump, R., \& Moench, E. (2013). Pricing the term structure with linear regressions. Journal of Financial Economics, 110, 110-138.

Adrian, T., Estrella, A., \& Shin, H. (2010). Monetary cycles, financial cycles, and the business cycle. Staff Report no. 421, Federal Reserve Bank of New York, New York, Ny.

Adrian, T., \& Shin, H. S. (2011). Financial intermediary balance sheet management. Annual Review of Financial Economics, 3, 289-307.

Ball, L., Gagnon, J., Honohan, P., \& Krogstrup, S. (2016). What else can central banks do? Geneva Reports on the World Economy 18.

Beck, T., Colciago, A., \& Pfajfar, D. (2014). The role of financial intermediaries in monetary policy transmission. Journal of Economic Dynamics and Control, 43, 1-11.

Belongia, M. T., \& Ireland, P. N. (2006). The own-price of money and the channels of monetary transmission. Journal of Money, Credit and Banking, 38, 429-445.

Benes, J., \& Kumhof, M. (2012). The Chicago plan revisited. IMF Working Paper, 12/202.

Bernanke, B. (2005). The global saving glut and the U.S. current account deficit. Remarks by Governor Ben S. Bernanke at the Sandridge Lecture, Virginia Association of Economists, Richmond, Virginia.

Bernanke, B. (2010). Statement before the financial crisis inquiry commission. 2 September 2010.

Bernanke, B., \& Blinder, A. (1988). Credit, money and aggregate demand. American Economic Review, $78(2), 435-439$.

Blanchard, O. (2016). Do DSGE models have a future? Policy Brief No. 16-11, Peterson Institute for International Economics, Washington, DC.

Blanchard, O. (2018). On the future of macroeconomic models. Oxford Review of Economic Policy, 34(1-2), 43-54.

Blanchard, O. J., \& Fischer, S. (1989). Lectures on macroeconomics. Cambridge, MA: MIT Press.

Blanchard, O. J., \& Leigh, D. (2013). Growth forecast errors and fiscal multipliers. American Economic Review, 103, 117-120.

Blinder, A. (1997). Is there a core of practical macroeconomics that we should all believe? American Economic Review, 87, 240-243.

Boissay, F., Collard, F., \& Smets, F. (2015). Booms and banking crises. Journal of Political Economy, 124(2), 489-538.

Borio, C., \& Zhu, H. (2012). Capital regulation, risk-taking and monetary policy: a missing link in the transmission mechanism? Journal of Financial Stability, 8, 236-251. 
Brunnermeier, M. (2009). Deciphering the liquidity and credit crunch 2007-2008. Journal of Economic Perspectives, 23, 77-100.

Brunnermeier, M. K. \& Sannikov, Y. (2015). The I theory of money. Unpublished manuscript.

Clerc, L., Derviz, A., Mendicino, C., Moyen, S., Nikolov, K., Stracca, L., Suarez, J., \& Vardoulakis, A. (2014). Capital regulation in a macroeconomic model with three layers of default. Unpublished Manuscript.

Daly, K. (2016). A secular increase in the equity risk premium. International Finance, 19, 179-200.

De Grauwe, P. (2010). The return of Keynes. International Finance, 13, 157-163.

Diamond, D., \& Rajan, R. (2000). A theory of bank capital. Journal of Finance, 55, 2431-2465.

Eggertsson, G. (2008). Liquidity trap. In S. Durlauf \& L. Blume (Eds.), The new Palgrave dictionary of economics (2nd ed.). New York: Palgrave Macmillan.

Eggertsson, G. B., \& Krugman, P. (2012). Debt, deleveraging, and the liquidity trap: A Fisher-Minsky-Koo approach. Quarterly Journal of Economics, 127, 1469-1513.

Flannery, M. (2015). Maintaining adequate bank capital. Journal of Money, Credit and Banking, 46, 157180.

FRED. (2015). Federal reserve economic data. http://research.stlouisfed.org/fred2/.

Gerali, A., Neri, S., Sessa, L., \& Signoretti, F. M. (2010). Credit and banking in a DSGE model of the euro area. Journal of Money, Credit and Banking, 42(s1), 107-141.

Gertler, M., \& Karadi, P. (2011). A model of unconventional monetary policy. Journal of Monetary Economics, 58, 17-34.

Gertler, M., Kiyotaki, N., \& Queralto, A. (2012). Financial crises, bank risk exposure and government financial policy. Journal of Monetary Economics, 59, s17-s34.

Goodfriend, M., \& McCallum, B. (2007). Banking and interest rates in monetary policy analysis: A quantitative exploration. Journal of Monetary Economics, 54, 1480-1507.

Gray, S. (2011). Central bank balances and reserve requirements. IMF Working Paper, 11/36.

Greenspan, A. (2005). Federal Reserve Board's semiannual Monetary Policy Report to the Congress before the Committee on Banking, Housing, and Urban Affairs. U.S. Senate. 16 February 2005.

Greenspan, A. (2010). Testimony to the financial crisis inquiry commission. 7 April 2010.

Hancock, D., \& Passmore, W. (2011). Did the Federal Reserve's MBS purchase program lower mortgage rates? Journal of Monetary Economics, 58, 498-514.

Hanson, S., Shleifer, A., Vishny, R., \& Stein, J. (2015). Banks as patient fixed-income investors. Journal of Financial Economics, 117, 449-469.

Hicks, J. R. (1937). Mr. Keynes and the "classics"; a suggested interpretation. Econometrica, 5, 147-159.

IMF. (2014). World economic outlook. Washington, DC: International Monetary Fund.

Kashyap, A., \& Stein, J. (1994). Monetary policy and bank lending. In N. Mankiw (Ed.), Monetary Policy (pp. 221-256). Chicago, IL: University of Chicago Press.

Keynes, J. M. (1936). The general theory of employment interest and money. London, UK: Macmillan.

Krugman, P. R. (1998). It's baaack: Japan's slump and the return of the liquidity trap. Brookings Papers on Economic Activity, 29, 137-205.

Krugman, P. R. (2000). How complicated does the model have to be? Oxford Review of Economic Policy, $16,33-42$.

Krugman, P. (2018). Good enough for government work? Macroeconomics since the crisis. Oxford Review of Economic Policy, 34(1-2), 156-168.

Kydland, F., \& Prescott, E. (1990). Business cycles: Real facts and a monetary myth. Federal Reserve Bank of Minneapolis Quarterly Review 14.

Lukkezen, J., Jacobs, B., \& Kool, C. (2015). Macro-economics of balance sheet problems and the liquidity trap. CPB Netherlands Bureau for Economic Policy Analysis.

Mankiw, N. G. (2006). The macroeconomist as a scientist and engineer. Journal of Economic Perspectives, 20, 29-46.

McLeay, M., Radia, A., \& Thomas, R. (2014). Money creation in the modern economy. Bank of England Quarterly Bulletin, p. Q1.

Michaillat, P., \& Saez, E. (2014). An economical business-cycle model. NBER-Working Paper 19777, National Bureau of Economic Research.

Moreira, A., \& Savov, A. (2014). The macroeconomics of shadow banking. Unpublished Manuscript.

Peek, J., \& Rosengren, E. (2014). The role of banks in the transmission of monetary policy. In A. Berger, P. Molyneux, \& J. Wilson (Eds.), The Oxford handbook of banking. Oxford, UK: Oxford University Press. 
Rochet, J. (2015). The bank capital controversy. European Economy-Banks, Regulation, and the Real Sector, 1, 39-46.

Romer, D. (2000). Keynesian Macroeconomics without the LM Curve. Journal of Economic Perspectives, 14, 149-169.

Stiglitz, J. E. (2018). Where modern macroeconomics went wrong. Oxford Review of Economic Policy, 34(1-2), 70-106.

Taylor, J. B. (1993). Discretion versus policy rules in practice. Carnegie-Rochester Conference Series on Public Policy, 39, 195-214.

Van den Heuvel, S. (2008). The welfare cost of bank capital requirements. Journal of Monetary Economics, 55, 298-320.

Van den Heuvel, S. (2002). The bank capital channel of monetary policy. Unpublished manuscript, University of Pennsylvania.

Vines, D., \& Wills, S. (2018). The rebuilding macroeconomic theory project: An analytical assessment. Oxford Review of Economic Policy, 34(1-2), 1-42.

Woodford, M. (2010). Financial intermediation and macroeconomic analysis. Journal of Economic Perspectives, 24, 21-44.

World Bank. (2015). World development indicators. http://data.worldbank.org/.

Wren-Lewis, S. (2018). Ending the microfoundations hegemony. Oxford Review of Economic Policy, 34(12), 55-69. 